\title{
EFFECT OF DIFFERENT SEED-BED PREPARATION SYSTEMS WITH ADDITION OF RICE STRAW ON SOME PHYSICAL SOIL PROPERTIES AND WHEAT YIELD

\author{
H. S. Abdel-Galil* AND E. A. A. El-SAYAD**
} \\ ABESTRACT
}

The purpose of this investigation was to study the effect of different seedbed preparation systems with addition of rice straw on some soil physical properties, rice straw distribution and wheat seed yield. To achieve this goal, the following treatments were used and tested: Chisel plow (tow passes) followed by land leveler with rice straw $\left(C h_{2} \cdot L+S\right)$, Chisel plow (one pass) followed by rotary plow with rice straw $\left(C h_{1} \cdot R+S\right)$, Rotary plow (one pass) with rice straw $(R+S)$ and Chisel plow (tow passes) followed by land leveler without addition rice straw as traditional system or control (Ch2.L). The wheat crop variety of (Shakha 69) was used and planted at prepared flat land by a mechanical drilling (seed drill). The field experiments were carried out in a loamy soil at the Farm of Fac. of Agric., Fayoum Univ. Fayoum Governorate. The results obtained from the present investigation could be summarized as follows: the conservation and reduced tillage treatments $\left(C h_{1} \cdot R+S\right.$ and $\left.R+S\right)$ were more effective for distribution and incorporating the added rice straw into the tested soil depth than the conventional tillage treatment (Ch. $h_{2}$. .). The conservation tillage treatment with rice straw $\left(C h_{1} . R+S\right)$ gave the lowest soil bulk density and highest soil porosity. The reduced tillage treatment with rice straw $(R+S)$ gave the lowest soil penetration resistance, regularity of seed distribution and high percentage of seedling emergence. The addition of rice straw to soil increased the biological and grain yield of wheat at all tillage treatments compared with conventional tillage treatment without rice straw. The use of rotary plow after chisel plough or using rotary plow alone considered as appropriate tillage system for wheat crop after rice harvesting. The use of rotary plow after chisel plow or using rotary plow alone gave the highest values of biological wheat yield (grain and straw).

* Assoc. Prof. of Agric. Eng., - Fac. of Agric. - Fayoum Univ. ** Prof. of Soil and Water - Fac. of Agric. - Fayoum Univ. 
It is concluded that the tillage systems with rotary plow only or after chisel plow improved the soil physical properties and recorded high crop yield of wheat.

\section{INTRODUCTION}

7 he effect of seed-bed preparation system on some physical properties of the soil varies considerably with the soil type, soil 1 moisture content at the time of operation, presence of plant residues and type of implements used. Tillage is one of the most fundamental and essential operations in agricultural production. It might be defined as the manipulation of soil to develop a desirable soil structure for seed-bed or root-bed to provide adequate air capacity and to establish specific surface configuration for planting operations. Al-Tahan et al. (1992) mentioned that the soil bulk density is affected by tillage treatments directly and indirectly. Direct effect of soil tillage is pulverized, distributed and its volume increased. Indirect effect of tillage happens when heavy machines and equipment pass over the soil which compacts it and its bulk density is increased. Suliman et al. (1993) used five different tillage treatment and they found that both the soil bulk density and the penetration resistance decreased after all the tillage treatments while, the penetration resistance increased with increasing the tillage depth. EL-Hanafy et al. (1995) stated that the use of chisel plow followed by rotary tiller can be recommended for tillage technique because it gave the best seed-bed preparation in terms of lowest value of clod mean diameter and the highest yield of barley. El-Said et al. (1998) found that the value of soil penetration resistance increased by increasing plowing depth, since increasing soil layer depth increased the soil compaction. Chauhan et al. (2000) indicated that no tillage technology for wheat after rice proved better in terms of saving of fuel, cost of cultivation and advancing sowing time than rotary cultivator and conventional tillage. Abo-Habaga (2003) used three tillage systems on a silt-clay soil (rotary tiller, chisel plow once followed by rotary tiller and chisel plow twice followed by wooden leveler). He recommended that the rotary tiller system recorded a lower soil roughness, lower penetration resistance and bulk density values at seed germination area, and also, 
obtained satisfactory crop yield in comparison with the other two systems. Suliman et al. (2003) recommended that the system of rotary plow followed by seed drill is the best one for seed-bed preparation and planting system of both fenugreek and mungbean crops. On other hand, the rotary plow was pulverized, crumbed the soil more and gave the lowest soil penetration resistance compared with the other seedbed preparation systems.

Ball and Robertson (1990) and Christian and Bacon (1991) reported that plowing is the most efficient residue incorporation method. Ali and Abo-Habaga (1995) stated that, the addition of the crop residues (shredded cotton stalks) during the seedbed preparation increased the wheat crop yield more than $20 \%$ in comparison with without crop residues. Dormaar and Carefoot (1996) indicated that crop residues may be incorporated partially or completely into the soil depending upon methods of cultivation. Powel and Unger (1997) indicated that the recycling of crop residues has the advantage of converting the surplus farm waste into useful product for meeting nutrient requirement of crops. It also, maintains the soil physical and chemical conditions and improves the overall ecological balance of the crop production system. Ghazy (2004) reported that using different sowing methods recorded higher crop yield about $11-20 \%$ with rice straw treatment more than the treatment without rice straw. Krishna et al. (2004) mentioned that rice straw incorporation coupled with organic manure increases wheat grain yield and improves soil physical condition. Residue incorporation results more microbial activity than residue removal or burning. Thus, if residues are managed properly, then it can warrant the improvements in soil properties and the sustainability in crop productivity.

The major aim of this research is to study the effect of different seed-bed preparation treatments and addition of rice straw on some soil physical properties, rice straw distribution and crop yield.

\section{MATERIAL AND METHODS}

This study was carried out at the experimental farm of the Faculty of Agriculture at Fayoum University during 2013/2014 growing season with an experimental area about two feddans. The experiments were carried out in a loamy soil. The soil moisture content was determined using the 
Oven method by drying the soil samples at $105^{\circ} \mathrm{C}$ for $24 \mathrm{~h}$. according to ASAE (1991). The experiments were executed at the optimum moisture content of the soil (friable stage). The moisture content, the soil bulk density and $\mathrm{pH}$ of the soil surface layer $(0-10 \mathrm{~cm})$ were determined before carrying out of the experimental treatments directly and found to be $12.4 \%, 1.382 \mathrm{~g} / \mathrm{cm}^{3}$ and 7.9 for the surface layer, respectively. The previous crop was rice and the average plowing depth was $20 \mathrm{~cm}$ for chisel plow and $10 \mathrm{~cm}$ for rotary plow. Seeding rate for seed drill was about $60 \mathrm{~kg}$. fed. ${ }^{-1}$.

1. Soil mechanical analysis: Before beginning the field experiments directly, nine soil samples were taken from three soil layers (0-10, 10- 20 and $20-30 \mathrm{~cm}$ ) to determine some physical properties of the studied soils. These samples were analyzed at the central soil laboratory of the Faculty of Agric., Fayoum Univ. Fayoum Governorate, Egypt. The results in Table (1) show the mechanical analysis, soil bulk density and the moisture content of the soil which indicated that the average amounts of soil fractions (\%) were $46.60 \%$ sand, $32.66 \%$ silt and $21.74 \%$ clay. Thus, the soil texture was classified as a loamy soil.

Table (1): Mechanical analysis, bulk density and moisture content of the soil.

\begin{tabular}{|c|c|c|c|c|c|c|}
\hline \multirow[b]{2}{*}{$\begin{array}{l}\text { Soil depth, } \\
\text { (cm) }\end{array}$} & \multicolumn{4}{|c|}{ Particle size ditribution } & \multirow{2}{*}{$\begin{array}{c}\text { Bull } \\
\text { density } \\
\left(\mathrm{g} / \mathrm{cm}^{3}\right)\end{array}$} & \multirow{2}{*}{$\begin{array}{l}\text { Soil moisture } \\
\text { content, } \\
(\%)\end{array}$} \\
\hline & $\begin{array}{c}\text { Sand } \\
(\%)\end{array}$ & \begin{tabular}{|c|} 
Silt \\
$(\%)$
\end{tabular} & $\begin{array}{l}\text { Clay } \\
(\%)\end{array}$ & $\begin{array}{c}\text { Texture } \\
\text { class }\end{array}$ & & \\
\hline $0-10$ & 45.46 & 33.27 & 20.80 & $L^{*}$ & 1.44 & 13.16 \\
\hline $10-20$ & 46.02 & 32.18 & 21.80 & $\mathbf{L}^{*}$ & 1.49 & 14.68 \\
\hline $20-30$ & 45.33 & 32.07 & 22.60 & $\mathbf{L}^{*}$ & 1.53 & 14.26 \\
\hline Average & 45.60 & 32.66 & 21.74 & $\mathbf{L}^{*}$ & 1.49 & 14.03 \\
\hline
\end{tabular}

$L^{\star}=$ Loamy soil texture

2. Implements specifications: The specifications of the agricultural tractor and implements used in this study were summarized as shown in Table (2).

\section{Experimental procedure:}

3.1. Experimental design and tillage methods: To fulfill the objective of this study, an experiment having an area of about 2.0 feddans was established as a split plots in three replicates. 
Table (2): Some specifications of the agicultural tractor and implements.

\begin{tabular}{|c|l|}
\hline Implement & \multicolumn{1}{|c|}{ Specifications } \\
\hline Tractor & $\begin{array}{l}\text { Romanian Universal } 650 \text {, with } 35.1 \mathrm{~kW}(47 \mathrm{hp}) \text { - The power } \\
\text { tack off }(\mathrm{P} . \mathrm{T} . \mathrm{O}) \text { is powered at } 1000 \text { and } 540 \mathrm{pm} \text {. }\end{array}$ \\
\hline Rotary plow & $\begin{array}{l}\text { EMAGRO, mounted with } 180 \mathrm{~cm} \text { working width - } 36 \text { rotating } \\
\text { blades of L-shape fixed on rotative shaft in } 9 \text { groups . }\end{array}$ \\
\hline Chisel plow & Mounted - 7 blades with $1.75 \mathrm{~cm}$ working width . \\
\hline Land leveler & $\begin{array}{l}\text { Mounted - three-point linkage - controled by tractor hydraulic- } \\
180 \text { cm working width. }\end{array}$ \\
\hline Seed drill & $\begin{array}{l}\text { EMAGRO "Mechanical Drilling" - Model No. } 2500 \text { - } 200 \mathrm{~cm} \\
\text { working width. }\end{array}$ \\
\hline
\end{tabular}

This area divided into four main plots involved four tillage systems. According to ASAE (1991), the tillage systems which were used in this study can be classified as follows:

- Conventional tillage \{chisel plow (tow passes) followed by land leveler $\left.\left(\mathrm{Ch}_{2} . \mathrm{L}\right)\right\}$.

- Conservation tillage \{chisel plow (one pass) followed by rotary plow $\left.\left(\mathrm{Ch}_{1} \cdot \mathrm{R}\right)\right\}$.

- Reduced tillage $\{$ one pass rotary plow $(\mathrm{R})\}$.

Flappers are to be attached to combine for shredding of rice straw and spread them more uniformly on the soil surface. After spread the rice straw (S) on three main plots of the experimental area, each one of them was tilled by one of the above tillage systems, whereas the conventional tillage system was used also, at the fourth main plot without addition of rice straw. The wheat crop variety of (Shakha 69) was used and planted at prepared flat land by a mechanical drilling (seed drill). All the experimental plots were under the same conditions in terms of type of sowing method, irrigation, fertilization, weed control and the other agricultural processes. The description of seedbed preparation systems was shown in Table (3).

3.2. Harvesting: Before harvesting the wheat crop, the crop yield was evaluated by taking three randomized samples from each main plot using a wooden square frame $\left(1 \mathrm{~m}^{2}\right)$ as a simpler. 
Table (3): Description of seed-bed preparation systems.

\begin{tabular}{|c|l|}
\hline System & \multicolumn{1}{|c|}{ Description of system } \\
\hline $\mathrm{Ch}_{2} \mathrm{~L}+\mathrm{S}$ & $\begin{array}{l}\text { Chisel plow (two passes) followed by land leveler } \\
\text { with rice straw. }\end{array}$ \\
\hline $\mathrm{C} \mathrm{h}_{\mathbf{l}} \mathrm{R}+\mathrm{S}$ & $\begin{array}{l}\text { Chisel plow (one pass) followed by rotary plow } \\
\text { with rice straw. }\end{array}$ \\
\hline $\mathrm{R}+\mathrm{S}$ & Rotary plow (one pass) with rice straw. \\
\hline $\mathrm{Ch}_{2} \mathrm{~L}$ & $\begin{array}{l}\text { Chisel plow (two passes) followed by land leveler } \\
\text { without rice straw (traditional system or control). }\end{array}$ \\
\hline
\end{tabular}

These samples were shelled by hand and weighed and used to extrapolate the crop yield in related to the feddan. The yield was expressed as dry matter weights. Finally, the wheat crop was harvested using a mounted mower and threshing by thresher.

\section{Measurements:}

4.1. Soil bulk density $\left(\rho_{\mathrm{b}}\right)$ : Soil bulk density was measured using the core sampler method. It was calculated using the following equation:

$$
\rho_{\mathrm{b}}=\mathrm{M}_{\mathrm{b}} / \mathrm{V}_{\mathrm{b}},\left(\mathrm{g} \cdot \mathrm{cm}^{-3}\right)
$$

Where: $M_{b}$ is the soil dry weight, $g$ and $V_{b}$ is the core volume, $\mathrm{cm}^{3}$.

The relative reduction of soil bulk density $\left(\mathrm{R}_{\mathrm{r}}\right.$. S.B.D.) was calculated as follows:

$$
R_{r} \cdot \rho_{b}=\left(\rho_{b 1}-\rho_{b 2}\right) / \rho_{b 1} \times 100,(\%)
$$

Where: $\boldsymbol{\rho}_{\mathbf{b} 1}$ and $\boldsymbol{\rho}_{\mathbf{b} 2}$ are the soil bulk densities before and after treatments, (g. $\left.\mathrm{cm}^{-3}\right)$.

4.2. Soil porosity (S.P): The soil porosity was calculated by using the following formula (Suliman et al., 2003):

$$
\text { S.P }=1-\left(\rho_{\mathrm{b}} / \rho_{\mathrm{s}}\right) \times 100,(\%)
$$

Where: $\rho_{\mathrm{s}}$ is the real soil density, considered $2.65 \mathrm{~g} . \mathrm{cm}^{-3}$,(Landon, 1991).

4.3. Soil penetration resistance (S.P.R): It was measured using a handle local manufactured penetrometer at three locations for each plot at depths of 5, 10, 13 and $16 \mathrm{~cm}$. El-Saadawy et al. (2004) stated that the specific resistance of the soil to penetrometer is due to the weight of the falling 
load potential energy and the weight of both the falling load and the vertical shaft. According to this fact, the required energy (R. E.) to drive the penetrometer into the soil is expressed as follows:

$$
\text { R.E. }=\left(\left(\mathrm{W}_{1} \cdot \mathrm{N} . \mathrm{H}\right)+\mathrm{D}\left(\mathrm{W}_{1}+\mathrm{W}_{2}\right)\right) \text {, }
$$

Where: $\mathrm{W}_{1}$ and $\mathrm{W}_{2}$ are weights of falling load and vertical shaft, $\left(\mathrm{kg}_{f}\right)$.

$\mathrm{N}$ is the number of impacts, (-).

$\mathrm{H}$ is the absolute height of the load fall, $(\mathrm{cm})$.

$\mathrm{D}$ is the depth of penetration, (cm).

Since, the soil resistance force $(F)$ is defined as the rate of energy change (E), with respect to the depth (D), hence:

$$
\mathrm{F}=(\mathrm{d}(\mathrm{R} . \mathrm{E}) / \mathrm{dD})=(\mathrm{W} 1 * \mathrm{~N} * \mathrm{H}) / \mathrm{D}+(\mathrm{w} 1+\mathrm{W} 2)
$$

Then, S. P. R. $\left(\mathrm{kg} . \mathrm{cm}^{-2}\right)$ was calculated as follows:

S. P. R. $=(\mathrm{F} / \mathrm{A})=\left(\left(\mathrm{W}_{1} * \mathrm{~N} * \mathrm{H}\right) / \mathrm{AD}\right)+\left(\left(\mathrm{W}_{1}+\mathrm{W}_{2}\right) / \mathrm{A}\right)=$

$(\mathrm{N} / \mathrm{D}) \times\left(\left(\mathrm{W}_{1} * \mathrm{H}\right) / \mathrm{A}\right)+\left(\left(\mathrm{W}_{1}+\mathrm{W}_{2}\right)----\right.$

Where: $\mathrm{A}$ is cross section area of the probe tip, $\left(\mathrm{cm}^{2}\right)$.

$$
\text { S. P. R. }=((\mathrm{N} / \mathrm{D}) \times \mathrm{C} 1)+\mathrm{C} 2,\left(\mathrm{~kg}_{f} \cdot \mathrm{cm}^{-2}\right)
$$

Where: $\mathrm{C} 1=\left(\mathrm{W}_{1} * \mathrm{H}\right) / \mathrm{A},\left(\mathrm{kg} \cdot \mathrm{cm}^{-2}\right)$ and $\mathrm{C} 2=\left(\mathrm{W}_{1}+\mathrm{W}_{2}\right) / \mathrm{A},\left(\mathrm{kg}_{f} \cdot \mathrm{cm}^{-2}\right)$

From the above equation, it is clear that the number of impacts

$(\mathrm{N})$ is a function of the penetration depth (D).

4.4. Theoretical field capacity (T.F.C): It was calculated as follows:

T.F.C $=(\mathrm{S} \times \mathrm{W}) / 4.2,\left(\mathrm{fed} . \mathrm{h}^{-1}\right)$

Where: $\mathrm{S}$ is the operating speed $\left(\mathrm{km} \cdot \mathrm{h}^{-1}\right)$, and $\mathrm{W}$ is the operating width $(\mathrm{m})$

4.5. Actual field capacity (A.F.C.): It was calculated as follows:

$$
\text { A.F.C. }=1 /\left(A_{t} / 60\right),\left(\text { fed. } h^{-1}\right)
$$

Where: $A_{t}=N_{t}+T_{t}+P_{t}$, h. fed. ${ }^{-1}$.

$A_{t}$ is the total actual plowing time per fed., min. fed ${ }^{-1} ; T_{t}$ is the turning time (Time of run per min. x No. of turns per fed., min. fed. $^{-1}$ and $P_{t}$ is the parasitic time, min. fed. ${ }^{-1}$.

4.6. Field efficiency (F.E.): It was calculated as follows:

F.E. $=(($ A. F. C. $) \times 100) /($ Th. F.C. $),(\%)$

4.7. Yield index: The yield index was calculated by using the following formula (Mahmoud, 1998) as follows:

Yield index = Economic seed yield, $\left(\mathrm{kg} . f e d .^{-1}\right) /$ Biological yield, $\left(\mathrm{kg} . \mathrm{fed} \cdot{ }^{-1}\right) .(11)$ 


\section{RESULTS AND DISCUSSION}

The obtained results were demonstrated and discussed as follows:

\section{Effect of different seed-bed preparation treatments on rice straw} distribution: For facilitating drill operation, the flapper are to be attached to combine for shredding of rice straw and spread them more uniformly on the soil surface of three main plots. Traditionally, rice straw is removed from the fourth main plot.

Fig. (1) shows the effect of seed-bed preparation on the rice straw distribution into the soil surface. The obtained results showed that using chisel plow once followed by rotary plow $\left(\mathrm{Ch}_{1} \cdot \mathrm{R}\right)$ as primary tillage had a good effect of transportation about $36 \%$ and $64 \%$ of separated rice straw from soil surface down to layer of $10-20 \mathrm{~cm}$ and $0-10$ depth, respectively, while, using the chisel plow twice followed by rotary plow $\left(\mathrm{Ch}_{2} . \mathrm{R}\right)$ transported about $42 \%$ and $58 \%$ of separated rice straw from soil surface down to layer of 10-20 $\mathrm{cm}$ and 0-10 depth, respectively. On the other hand, we can say that the chisel plow (one and two passes) transported about $33 \%$ and $42 \%$ of separated rice straw from soil surface down to layer of $10-20 \mathrm{~cm}$, respectively, while the rotary plow distributed the rest of separated straw (67\% and 58\%) into surface soil layer until $10 \mathrm{~cm}$ depth uniformity.

Using the rotary plow treatment only distributed the rice straw in the tilled soil into $100 \%$ at $0-10 \mathrm{~cm}$ depth.

The reason is to be in the chisel plow led to increasing the tillage depth, while, the rotary plow incorporated the rice straw very well through the surface layers until $10 \mathrm{~cm}$ depth.

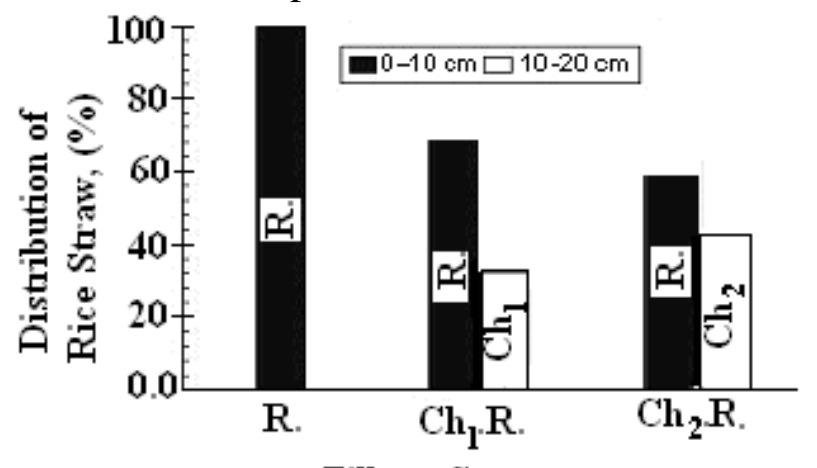

Tillage System

Fig. (1): Effect of tillage systems on rice straw distribution. 
The obtained results revealed that rotary plow in reduced and conservation tillage systems led to incorporated the rice straw into the soil, moreover accomplishing a clean seedbed.

\section{Effect of different seed-bed preparation systems and rice straw} on some soil physical properties: Soil bulk density and the soil porosity were determined before carrying out of the experimental treatments directly and found to be $1.182 \mathrm{~g} / \mathrm{cm}^{3}$ and 56.24 , respectively. Table (4) shows the data obtained for the values of both soil bulk density and soil porosity before and after the tillage operation systems.

2.1. Soil bulk density: From the data in Table (4), it is clear that the values of soil bulk density were decreased after all seed-bed preparation systems compared with that before treatments (no-tillage). The lowest values of soil bulk density $\left(0.724\right.$ and $\left.0.764 \mathrm{~g} . \mathrm{cm}^{-3}\right)$ were obtained after incorporated the rice straw on the soil with both the conservation tillage $\left(\mathrm{Ch}_{1} \cdot \mathrm{R}+\mathrm{S}\right)$ and conventional tillage $\left(\mathrm{Ch}_{2} \cdot \mathrm{L}+\mathrm{S}\right)$, respectively. But the highest value $\left(0.868 \mathrm{~g} . \mathrm{cm}^{-3}\right)$ was obtained with the conventional tillage system $\left(\mathrm{Ch}_{2} . \mathrm{L}\right)$ without addition of rice straw on the soil compared with that the other seed-bed preparation systems. This trend may be due to that the effect of the working organ type (implement blades) on the soil. On the other hand, these changes may be depending on the degree of stirring or inverting or pulverizing soil structure.

Table (4): Effect of different seed-bed preparation systems on soil bulk density and soil porosity.

\begin{tabular}{|c|c|c|c|c|}
\hline $\begin{array}{c}\text { Seed-bed } \\
\text { preparation } \\
\text { system }\end{array}$ & $\begin{array}{c}\text { Soil bulk } \\
\text { density, } \\
\left(\mathrm{g} . \mathrm{cm}^{\mathbf{3}}\right)\end{array}$ & $\begin{array}{c}\text { Relative } \\
\text { reduction of } \\
\text { bulk density } \\
(\%)\end{array}$ & $\begin{array}{c}\text { Soil } \\
\text { poorosity, } \\
(\%)\end{array}$ & $\begin{array}{c}\text { Relative } \\
\text { increasing of } \\
\text { soil porosity, } \\
(\%)\end{array}$ \\
\hline $\mathrm{Ch}_{\mathbf{2}} \cdot \mathrm{L}+\mathrm{S}$ & $\mathbf{0 . 7 6 4}$ & 35.25 & 73.02 & 29.84 \\
\hline $\mathrm{Ch}_{\mathbf{1}} \cdot \mathrm{R}+\mathrm{S}$ & $\mathbf{0 . 7 2 4}$ & 38.64 & 73.82 & 31.26 \\
\hline $\mathrm{R}+\mathrm{S}$ & 0.801 & 32.12 & 72.42 & 28.77 \\
\hline $\mathrm{Ch}_{\mathbf{2}} \mathrm{L}$ & 0.868 & 26.44 & 69.92 & 24.32 \\
\hline $\begin{array}{c}\text { Before } \\
\text { treatment }\end{array}$ & 1.180 & - & 56.24 & - \\
\hline
\end{tabular}


So, chisel plow penetrates the soil, breaks up and disturbs the soil without inverting it that has a little effect on dispersing soil particles. But the rotary plow stirs, pulverizes, crumbs and increases the soil distribution volume much more than the chisel plow. This result is agreed with the obtained result by Al-Tahan et al. (1992); Metwalli $\boldsymbol{e t}$ al., (2000) and Suliman et al., (2003).

2.2. Soil porosity: The data shown in Table (4) indicated that soil porosity values were increased after all seed-bed preparation treatments than those before treatments. It is clear that the soil porosity shows a reverse behavior as compared with the changes in soil bulk density at all seed-bed preparation treatments. These results are in agreement with Abdel-Aal et al. (2005).

2.3. Soil penetration resistance: The soil penetration resistance has a good indicator of soil physical properties. The decrease of soil penetration resistance allows the roots of plants easily to penetrate the soil and grow. The soil penetration resistance was measured before and after all seed-bed preparation treatments at depths of 10 and $20 \mathrm{~cm}$. The obtained data are shown in Table (5). From these data, it is clear that the seed-bed preparation system and tillage depth played an important role on resistance of the seed-bed. So, the soil penetration resistance was decreased after all seed-bed preparation systems compared with that before treatment. The soil penetration resistance was increased with the increase of plowing depth. These results indicated also, that the reduced tillage treatment \{one pass rotary plow (R) \} gave the lowest values of penetration resistance. Generally, using chisel plough reduced the soil penetration resistance, meanwhile the conservation tillage $\left(\mathrm{Ch}_{1} \cdot \mathrm{R}+\mathrm{S}\right)$ and conventional tillage $\left(\mathrm{Ch}_{2} \cdot \mathrm{L}+\mathrm{S}\right)$ at soil with rice straw recorded increasing of penetration resistance. The conservation tillage treatment $\left(\mathrm{Ch}_{1} \cdot \mathrm{R}+\mathrm{S}\right)$ recorded the minimum penetration resistance at both 10 and $20 \mathrm{~cm}$ tillage depths in comparison with conventional tillage $\left(\mathrm{Ch}_{2} \cdot \mathrm{L}+\mathrm{S}\right)$. After three months, the treatments $\left(\mathrm{R}+\mathrm{S}, \mathrm{Ch}_{1} \cdot \mathrm{R}+\mathrm{S}\right.$ and $\left.\mathrm{Ch}_{2}-\mathrm{L}+\mathrm{S}\right)$ recorded a few increasing of soil penetration resistance in comparison with conventional tillage without rice straw $\left(\mathrm{Ch}_{2}\right.$.L without $\left.\mathrm{S}\right)$. It is also clear that the lowest 
values of soil penetration resistance at both depths were obtained using the reduced tillage treatment \{one pass rotary plow $(\mathrm{R})\}$. This trend may be due to the fact that rotary plow is pulverized and crumbled the soil more than the other seed-bed preparation systems.

Generally, it may be noted that tillage systems with rotary plow as a primary tillage or after chiseling at soil had rice straw improved the soil properties and recorded high crop yield (wheat).

Table (5): Effect of different seed-bed preparation systems and rice straw on soil penetration resistance.

\begin{tabular}{|c|c|c|}
\hline \multirow{2}{*}{$\begin{array}{c}\text { Seed-bed } \\
\text { preparation } \\
\text { system }\end{array}$} & \multicolumn{2}{|c|}{ Tillage depth, cm } \\
\cline { 2 - 3 } & $0-10$ & $0-20$ \\
\hline Ch2L + S & 0.84 & 1.71 \\
\hline Chl.R + S & 0.76 & 1.41 \\
\hline $\mathrm{R}+\mathrm{S}$ & 0.39 & 0.88 \\
\hline Cln $\mathrm{L}$ & 0.41 & 1.28 \\
\hline $\begin{array}{c}\text { Before } \\
\text { treatment }\end{array}$ & 1.96 & 3.36 \\
\hline
\end{tabular}

3. Field capacity and field efficiency for different seed-bed preparation systems: The field capacity and field efficiency were calculated for different seed-bed preparation systems. The average forward speeds for chisel plow were 3.60 and $3.86 \mathrm{~km} . \mathrm{h}^{-1}$ in the first and second passes, respectively, but the average forward speeds for rotary plow and seed drill were 4.20 and $5.20 \mathrm{~km} . \mathrm{h}^{-1}$, respectively. The data obtained are shown in Table (6), from these data, it is clear that the reduced tillage \{one pass rotary plow $(\mathrm{R})$ \}and seed drill planting \{ seed drill (SD) \} systems gave the highest value of actual field capacity (0.797 fed. $h^{-1}$ ), while the conventional tillage \{chisel plow (tow passes) followed by land leveler $\}$ and seed drill planting systems $\left(\mathrm{Ch}_{2} \cdot \mathrm{L}+\mathrm{SD}\right)$ gave the lowest value of actual field capacity $\left(0.338 \mathrm{fed}^{-1} \mathrm{~h}^{-1}\right)$, This trend may be due to the fact that the used of chisel plow two passes (two 
times), land leveler and seed drill (four operations) consumed the highest total actual time (theoretical, turning and waste time) that was (177.45 min. fed $^{-1}$ ) compared with that the other two systems. On the contrary, the use of rotary plow and seed drill (two operations) with the system of $(\mathrm{R}+\mathrm{SD})$ consumed the lowest total actual time (75.26 min./fed.) compared with that the other two systems. Generally, according to the high values of the actual field capacity for different seed-bed preparation systems, they can be arranged by the following descending order: ( $\mathrm{R}+$ $\mathrm{SD})>\left(\mathrm{Ch}_{1} \mathrm{R}+\mathrm{SD}\right)>\left(\mathrm{Ch}_{2} \cdot \mathrm{L}+\mathrm{SD}\right)$. It is also, clear from the tabulated data that the system $\left(\mathrm{Ch}_{2}\right.$. $\left.\mathrm{L}+\mathrm{SD}\right)$ gave the highest value of field efficiency (75.96\%). Generally, according to field efficiency for different systems can be arranged by the following descending order: $\left(\mathrm{Ch}_{2} \cdot \mathrm{L}+\right.$ $\mathrm{SD})>\left(\mathrm{Ch}_{1} \mathrm{R}+\mathrm{SD}\right)>(\mathrm{R}+\mathrm{SD})$.

Table (6): Field capacity and field efficiency for different seed-bed preparation treatments.

\begin{tabular}{|c|c|c|c|c|c|c|c|c|c|}
\hline System & Treaqtment & $\begin{array}{c}\text { Width: } \\
\text { m }\end{array}$ & $\begin{array}{r}\text { Net time } \\
-1 \\
\text { min.fed. }\end{array}$ & $\begin{array}{l}\text { Turning } \\
\text { time } \\
\text { min.fed. }\end{array}$ & $\begin{array}{l}\text { Parasitic } \\
\text { time } \\
\text { min.fed. }\end{array}$ & $\begin{array}{l}\text { Total } \\
\text { Actual } \\
\text { time } \\
\text { min.fed. }\end{array}$ & $\begin{array}{l}\text { Theo. } \\
\text { field } \\
\text { capacity: } \\
\text { fed. } \mathrm{h}^{-1}\end{array}$ & $\begin{array}{c}\text { Actual } \\
\text { field } \\
\text { capacity: } \\
\text { fed. } \mathbf{h}^{-1}\end{array}$ & $\begin{array}{c}\text { Field } \\
\text { efficiebcy } \\
\% \%\end{array}$ \\
\hline \multirow{5}{*}{$\begin{array}{c}\text { Ch2.L } \\
+ \\
\text { SD }\end{array}$} & $\begin{array}{l}\text { Chisel plow } \\
1^{\text {st pass }}\end{array}$ & 1.75 & 4138 & 6.24 & 6.14 & \multirow{5}{*}{177.45} & \multirow{5}{*}{0.445} & \multirow{5}{*}{0338} & \multirow{5}{*}{7596} \\
\hline & $\begin{array}{c}\text { Chisel plow } \\
2^{\text {nd }} \text { pass }\end{array}$ & 1.75 & 38.12 & 6.00 & 6.08 & & & & \\
\hline & Land leveler & 1.80 & 34.12 & 5.42 & 1.09 & & & & \\
\hline & Seed drill & 2.00 & 21.16 & 6.28 & 5.42 & & & & \\
\hline & Total & - & 134.78 & 23.94 & 18.73 & & & & \\
\hline \multirow{4}{*}{$\begin{array}{c}\text { Chl R } \\
+ \\
\text { SD }\end{array}$} & $\begin{array}{c}\text { Chisel plow } \\
1^{\text {st pass }}\end{array}$ & 1.75 & 4138 & 6.24 & 6.14 & \multirow{4}{*}{129.02} & \multirow{4}{*}{0.621} & \multirow{4}{*}{0.465} & \multirow{4}{*}{74.88} \\
\hline & Rotary plow & 1.80 & 34.06 & 5.88 & 2.46 & & & & \\
\hline & Seed drill & 2.00 & 21.16 & 6.28 & 5.42 & & & & \\
\hline & Total & - & 96.60 & 18.40 & 14.02 & & & & \\
\hline \multirow{3}{*}{$\begin{array}{c}\mathbf{R} \\
+ \\
\text { SD }\end{array}$} & Rotary plow & 1.80 & 34.06 & 5.88 & 2.46 & \multirow{3}{*}{75.26} & \multirow{3}{*}{1.087} & \multirow{3}{*}{0.797} & \multirow{3}{*}{7332} \\
\hline & Seed drill & 2.00 & 21.16 & 6.28 & 5.42 & & & & \\
\hline & Total & - & 55.22 & 12.16 & 7.88 & & & & \\
\hline
\end{tabular}




\section{Effect of different seed-bed preparation systems on seedling} emergence: For proper seed germination, wheat seeds should be planted at soil moisture content slightly higher than field capacity. High moisture keeps the soil strength low and allows good germination and root penetration. Fig. (2) shows that the reduced tillage treatment (R) leads to a higher emergence percentage after wheat seeds sowing and irrigation. It is also clear that the reduced tillage treatment $(\mathrm{R})$ recorded about $75 \%$ of seedling emergence, after 5 days from seeds sowing and irrigation. But, the conservation $\left(\mathrm{Ch}_{1} \mathrm{R}\right)$ and conventional $\left(\mathrm{Ch}_{2} \cdot \mathrm{L}\right)$ tillage treatments recorded $70 \%$ and $60 \%$ of seedling emergence, respectively. It is also clear that the seedling emergence completed in both of reduced (R) and conservation $\left(\mathrm{Ch}_{1} \mathrm{R}\right)$ tillage treatments after 13 and 15 days, respectively. Comparatively, the seedling emergence in conventional tillage treatment completed after 17 days. The increasing of the seedling emergence in case of reduced tillage is due to the decreasing of the clods size at the seed-bed surface and good distribution of seeds in the soil surface, and each seed had a good chance to expose to suitable environment such as temperature, light .... etc. On the other hand, the decreasing of seedling emergence percentage in the conventional tillage is due to the increasing of the clods size and sowing depth. Thus, the reduced tillage (R) may be considered the suitable tillage system to obtain regularity of seed distribution and high percentage of seedling emergence.

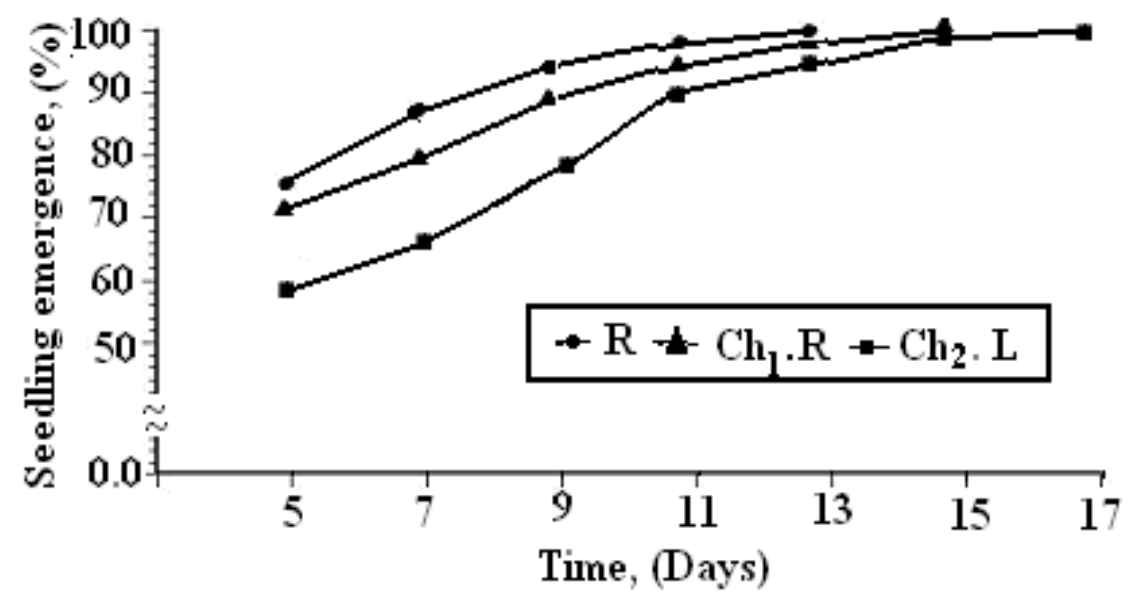

Fig. (2): Effect of different tillage systems on seedling emergence. 


\section{Effect of different seed-bed preparation systems and rice straw on} crop yield and yield index: Wheat yield includes the sum total of the following parameters: plant height, plant population (numbers of plants per fed.) and weight of 1000-grain (Table 7). From the obtained results, it is clear that there is a significant effect for seed-bed preparation systems and addition of rice straw to the soil on the wheat grains yield. The highest biological yield $\left(5144.69 \mathrm{~kg} \mathrm{fed}^{-1}\right)$ of the wheat crop was obtained by using conservation tillage treatment at soil has rice straw $\left(\mathrm{Ch}_{1} \cdot \mathrm{R}+\mathrm{S}\right)$. This system gave the highest grain and straw yield (3186.55 and $1497.53 \mathrm{~kg}$. fed. ${ }^{-1}$ ), respectively. On the hand, conservation tillage treatment at soil has rice straw $\left(\mathrm{Ch}_{1} \cdot \mathrm{R}+\mathrm{S}\right)$ recorded the higher crop yield in comparison with reduced $(\mathrm{R}+\mathrm{S})$ and conventional tillage $\left(\mathrm{Ch}_{2} \cdot \mathrm{L}+\mathrm{S}\right)$ systems. The results indicated that the addition of rice straw increasing the biological yield of wheat by about $11.22 \%, 8.51 \%$ and $6.18 \%$ at conservation, reduced and conventional tillage treatments more than the crop yield at conventional tillage treatment without rice straw $\left(\mathrm{Ch}_{2} \cdot \mathrm{L}\right)$, respectively. It is also, clear that the addition of rice straw increasing the grain yield of wheat by about $11.54 \%, 9.55 \%$ and $8.14 \%$ at conservation, reduced and conventional tillage treatments more than the crop yield at conventional tillage treatment without rice straw $\left(\mathrm{Ch}_{2} . \mathrm{L}\right)$, respectively.

Table (7): Effect of different seed-bed preparation treatments and addition of rice straw on crop yield and yield index.

\begin{tabular}{|c|c|c|c|c|c|c|c|}
\hline $\begin{array}{c}\text { Seed-bed } \\
\text { preparation } \\
\text { treatment }\end{array}$ & $\begin{array}{c}\text { Average } \\
\text { plant } \\
\text { height, } \\
\text { (cm) }\end{array}$ & $\begin{array}{c}\text { Average No. } \\
\text { of plant, } \\
\text { (plant/fed) }\end{array}$ & $\begin{array}{c}\text { Average } \\
\text { Weight } \\
\text { of l000 } \\
\text { grain, (g) }\end{array}$ & $\begin{array}{c}\text { Average } \\
\text { biological } \\
\text { yield, } \\
\text { (keg/fed) }\end{array}$ & $\begin{array}{c}\text { Average } \\
\text { grain } \\
\text { yield, } \\
\text { (keg/fed) })\end{array}$ & $\begin{array}{c}\text { Average } \\
\text { straw } \\
\text { yield, } \\
\text { (keg/fed) }\end{array}$ & $\begin{array}{l}\text { Yield } \\
\text { index } \\
(\% 6)\end{array}$ \\
\hline Ch2.L+ S* & 128 & 458675 & 44.06 & 4911.30 & 3089.24 & 1822.06 & 62.90 \\
\hline Ch.R+ S* & 136 & 460234 & 45.08 & 5144.69 & 3186.55 & 1908.14 & 61.93 \\
\hline R+S* & 132 & 459990 & 44.98 & 5019.06 & 3129.73 & 1889.33 & 62.35 \\
\hline Ch2.L & 124 & 457988 & 43.82 & 4625.66 & 2856.68 & 1786.98 & 61.75 \\
\hline
\end{tabular}

$\mathrm{S}^{\star}=$ rice straw

From the above results, it may be noted that using the rotary plow after chisel plough or using rotary plow alone considered as appropriate tillage 
system for wheat crop after rice harvesting. Finally, the results indicated that the use of rotary plow after chisel plow or using rotary plow alone gave the highest values of biological wheat yield (grain and straw). This may be due to that the use the use of rotary plow gave lowest values of soil penetration resistance which help the root system of plants to penetrate the soil easily. Generally, seed yield can be arranged as affected by seed-bed preparation systems and addition of rice straw as the following descending order: $\mathrm{Ch}_{1} \cdot \mathrm{R}+\mathrm{S}>\mathrm{R}+\mathrm{S}>\mathrm{Ch}_{2} \cdot \mathrm{L}+\mathrm{S}>\mathrm{Ch}_{2} \cdot \mathrm{L}$.

\section{CONCLUSION}

The aim of this research was to study the effect of different seed-bed preparation treatments and addition of rice straw on some soil physical properties, rice straw distribution and crop yield (wheat). This study was carried out at the experimental farm of the Fac. of Agric. at Fayoum Governorate. The experiments were carried out in a loamy soil. To achieve this goal, the following treatments were used and tested:

$\mathrm{Ch}_{2} \cdot \mathrm{L}+\mathrm{S}$ : Chisel plow (tow passes) followed by land leveler with rice straw. $\mathrm{Ch}_{1} \cdot \mathrm{R}+\mathrm{S}$ : Chisel plow (one pass) followed by rotary plow with rice straw. $\mathrm{R}+\mathrm{S} \quad$ : Rotary plow (one pass) with rice straw.

$\mathrm{Ch}_{2} . \mathrm{L} \quad$ : Chisel plow (tow passes) followed by land leveler without rice straw.

\section{The obtained results can be summarized as follows:}

1. Using rotary plow in reduced and conservation tillage systems led to incorporated the rice straw into the soil, moreover accomplishing a clean seedbed.

2. Soil bulk density was decreased after all seed-bed preparation treatments as compared with that before treatments (no-tillage). The lowest values of soil bulk density $\left(0.724\right.$ and $\left.0.764 \mathrm{~g} . \mathrm{cm}^{-3}\right)$ were obtained after incorporated the rice straw on the soil with both the conservation tillage $\left(\mathrm{Ch}_{1} \cdot \mathrm{R}+\mathrm{S}\right)$ and conventional tillage $\left(\mathrm{Ch}_{2} \cdot \mathrm{L}+\mathrm{S}\right)$, respectively, while the highest value $\left(0.868 \mathrm{~g} . \mathrm{cm}^{-3}\right)$ was obtained with the conventional tillage system $\left(\mathrm{Ch}_{2} . \mathrm{L}\right)$ without addition of rice straw.

3. Soil porosity values were increased after all seed-bed preparation treatments than those before treatments. It showed a reverse behavior as compared with the changes in soil bulk density at all seed-bed preparation treatments. 
4. The soil penetration resistance was decreased after all seed-bed preparation systems compared with that before treatments at both plowing depths $(0-10$ and $0-20) \mathrm{cm})$ but, the soil penetration resistance was increased with the increase of plowing depth. The reduced tillage system with rice straw $(R+S)$ gave the lowest values of penetration resistance, but the conventional tillage system with rice straw $\left(\mathrm{Ch}_{2} \cdot \mathrm{L}+\mathrm{S}\right)$ gave the highest values of penetration resistance at both plowing depths. Generally, using chisel plough reduced the soil penetration resistance, meanwhile the conservation tillage $\left(\mathrm{Ch}_{1} \cdot \mathrm{R}+\mathrm{S}\right)$ and conventional tillage $\left(\mathrm{Ch}_{2} \cdot \mathrm{L}+\mathrm{S}\right)$ at soil with rice straw recorded increasing of penetration resistance.

5. The reduced tillage and seed drill planting systems \{one pass rotary plow $(\mathrm{R})+$ seed drill $(\mathrm{SD})\}$ gave the highest value of actual field capacity $\left(0.797\right.$ fed. $\left.h^{-1}\right)$, while the conventional tillage \{chisel plow (tow passes) followed by land leveler $\}$ and seed drill planting systems $\left(\mathrm{Ch}_{2} . \mathrm{L}+\mathrm{SD}\right)$ gave the lowest value of actual field capacity $(0.338$ fed. $\left.h^{-1}\right)$.

6. The reduced tillage (Rotary plow alone, R) may be considered the suitable tillage system to obtain regularity of seed distribution and high percentage of seedling emergence.

6. The addition of rice straw was increased the biological yield of wheat by about $11.22 \%, 8.51 \%$ and $6.18 \%$ at conservation, reduced and conventional tillage treatments more than the conventional tillage treatment without rice straw $\left(\mathrm{Ch}_{2} . \mathrm{L}\right)$, respectively, while addition of rice straw increasing the grain yield of wheat by about $11.54 \%, 9.55 \%$ and $8.14 \%$ at the same treatments more than at conventional tillage treatment without rice straw $\left(\mathrm{Ch}_{2} . \mathrm{L}\right)$, respectively.

7. The conservation tillage system and seed drill at soil has rice straw $\left(\mathrm{Ch}_{1} \cdot \mathrm{R}+\mathrm{S}\right)$ gave the highest value of biological wheat yield per feddan, but the conventional tillage system $\left(\mathrm{Ch}_{2} . \mathrm{L}\right)$ and seed drill without addition of rice straw gave the lowest value of biological wheat yield per feddan. The system of $\left(\mathrm{Ch}_{2} \cdot \mathrm{L}+\mathrm{S}\right)$ gave the highest value of yield index, but the system of $\left(\mathrm{Ch}_{2} . \mathrm{L}\right)$ gave the lowest value of yield index. 
8. Seed yield can be arranged as affected by seed-bed preparation systems and addition of rice straw as the following descending order: $\mathrm{Ch}_{1} \cdot \mathrm{R}+\mathrm{S}>\mathrm{R}+\mathrm{S}>\mathrm{Ch}_{2} \cdot \mathrm{L}+\mathrm{S}>\mathrm{Ch}_{2} \cdot \mathrm{L}$.

Finally, it can be recommended the reduced tillage system with rice straw followed by seed drill (R. SD $+\mathrm{S}$ ) which is the best treatment for seedbed preparation and planting system of wheat after rice harvesting under this experimental conditions. The farmer can be selecting the suitable seed-bed preparation system according to the type of implement available in the location area and the above descending order for wheat crop.

\section{REFERENCES}

Abdel-Aal, S. E.; Kishta, A. M. and Lotfy, A. (2005). Seedbed preparation and irrigation depths affecting soil physical properties and rice yield. Misr J. Agric. Eng., 22(2): 572-591.

Abo-Habaga, M. M. (2003). Effect of seed-bed preparation system on crop yield grandeur. The $11^{\text {th }}$ Annual Conference of Misr Society of Agric. Eng. Oct. 2003: 303-309

Ali, R. A. and Abo-Habaga, M. M. (1995). Chance of soil characteristics and wheat crop associated with recycling of cotton residues under different types of till Agric. systems". J. Agric. Sci. Mansoura Univ. 20(1): 461- 473.

ASAE. (1991). American Society of Agriculture Engineers. Agriculture machinery management, ASAE Standards. 1991.

Ball, B. C. and Robertson, E. A. G. (1990). Straw incorporation and tillage methods: Straw decomposition, denitrification and growth and yield of wheat. J. Agric. Eng. Res. 46:223-243.

Chauhan, D. S.; Sharma, R. K.; Tripathi, S. C.; Kharub, A. S. and Chokar, R. S. (2000). Wheat cultivation after rice- a paradigm shift in tillage technology. Indian Farming, September 2000:21$22 \& 38$.

Christian, D. G. and Bacon, E. T. G. (1991). The effect of straw disposal and depth of cultivation on the growth, nutrient uptake and yield of winter on a clay and silt soil. Soil Use Manage. 7:217-222. 
Dormaar, J. F. and Carefoot, J. M. (1996). Implications of crop residue management and conservation tillage on soil organic matter. Can. J. Plant Sci. 76:627-634.

EL-Hanafy, E. H.; Abd Alla, H. and Radwan, S. M. (1995). Effect of some seed-bed preparation systems on seed drill performance, soil physical properties and barley yield. Misr J. Agric. Eng., 12 (3): 591- 600.

El-Saadawy, M. A.; Mohamed A. I. and Bahnasy A. F. (2004). Effect of plowing depth on water requirement, draft force and soybean yield at Etay EL-Baroud region. 12 ${ }^{\text {th }}$ Conf. of Misr J. Agric. Eng., 12 (4): 285- 296.

Ghazy, M. (2004). Development of a combine machine for soil preparation and sowing clover crop. Ph.D. Thesis, Fac. of Agric., Mansoura Univ.: 1-83.

Krishna, G. M.; Arun, K. M.; Kuntal, M. H.; Kali, K. B.; Prabir, K. G. and Manoranjan, M. (2004). Rice residue-management options and effects on soil properties and crop productivity. Food, Agriculture \& Environment. Vol.2 (1): 224-231. 2004.

Landon, J. R. (1991). Tropical Soil Manual. John Wiley \& Sons, Inc. 605 Third Avenue, NY 10158.

Mahmoud, M. H. (1998). Effect of plant population density and weed control treatments on growth and yield of mungbean. M. Sc. Thesis. Agronomy Dept, Fac. of Agric., Cairo Univ.

Metwalli, M.E.M.; Abou-Shieshaa, R.R. ; Kholief, R. M. and Kanany, R.E. (2000). Effect of four different tillage systems and nitrogen sources on wheat production under improved salt affected soil. Misr J. Agric. Eng., 17(3): 539-554.

Powel, J. m. and Unger, P. W. (1997). Alternatives to crop residues as soil amendments. IN: Renard, C. (Ed.) Crop residues in sustainable mixed crop/livestock farming systems. ICRISAT, India and ILRI, Kenya. P. 215-239. 
Suliman, A. E.; Nassr G. M. and Adawy, W. M. I. (1993) A study on the effect of different tillage systems on the physical properties of the soil. Misr J. Agric. Eng., 10 (2):169- 189.

Suliman, A. E.; Nassr, G. M. and Mohamed, I. M. A. (2003). Effect of different seed-bed preparation and planting systems for some medicinal plants on some active constituents and yield. $11^{\text {th }}$ Annul Conf. of Misr Soc. of Agric. Eng., 15-16 Oct. 2003, 20(3): 747-772.

الملخص العربع

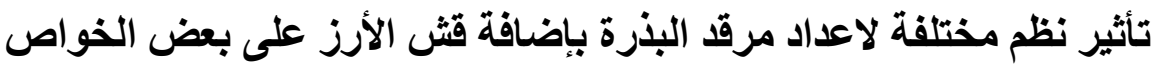

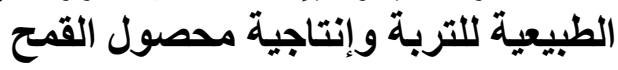

د / حمدى سالم السيدعبدالجليل أدد / إيهاب عبدالحليم على الصياد

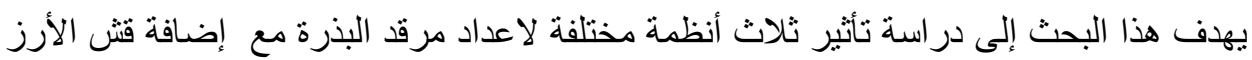

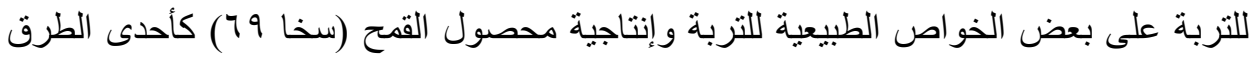

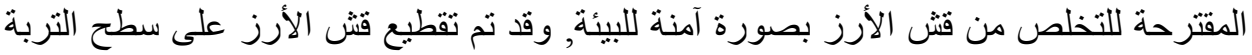

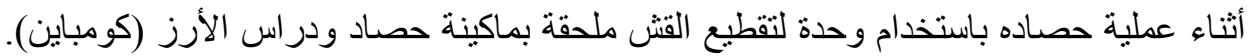
ولتحقيق هذا الهدف تم در اسة المعاملات الآتية:

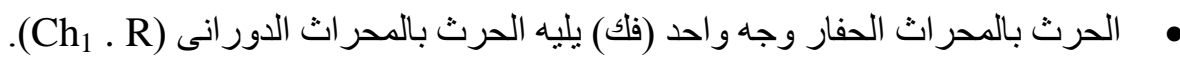

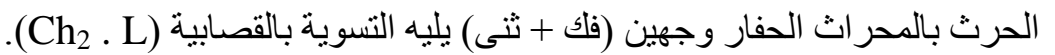

$$
\begin{aligned}
& \text { الحرث بالمحر اث الدور انى وجه واحد وجات (RD). } \\
& \text { الزراعة بالسطارة (SD). }
\end{aligned}
$$

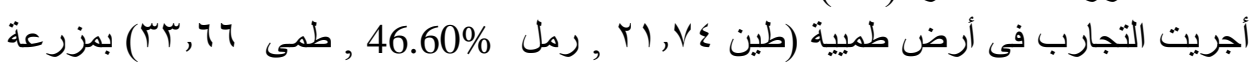
كلية الزر اعة بالفيوم - جامعة الفيوم. ألفيو

\section{ويمكن تلخبص النتائج التى تم الحصول عليها من هذه الدراسة كمايلي:}

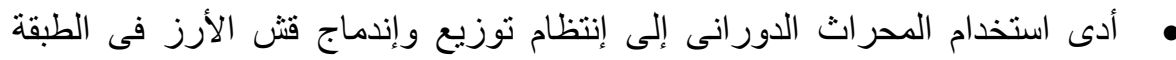

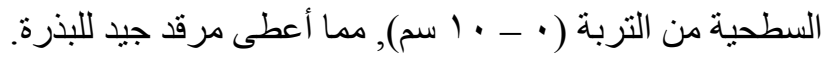

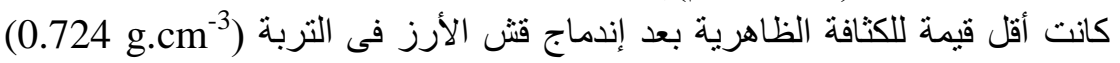
للنظام (الارز

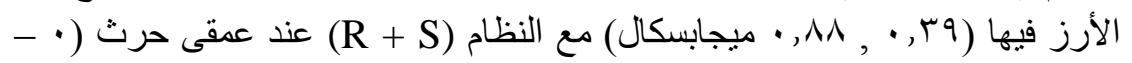

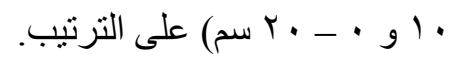

* أستاذ الهندسة الزراعية المساعد ـ كلية الزراعة ـ جامعة الفيوم.

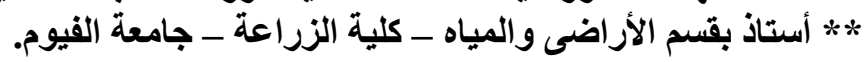




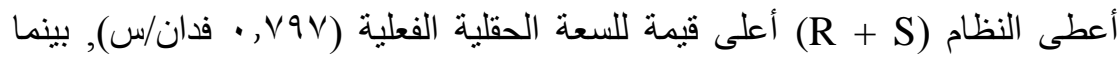

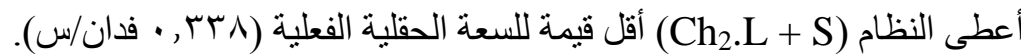

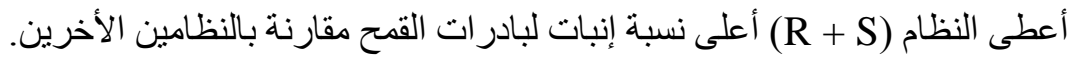

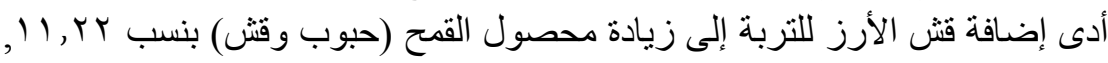

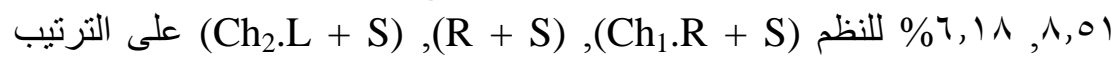

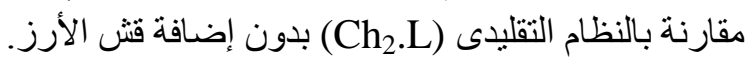

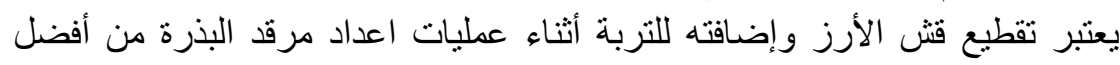

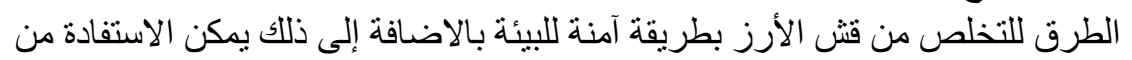

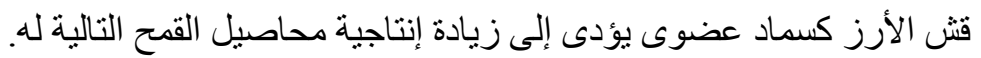

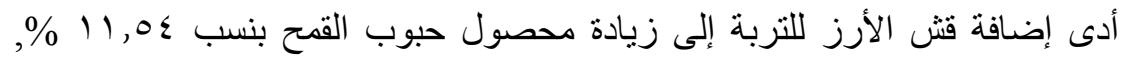

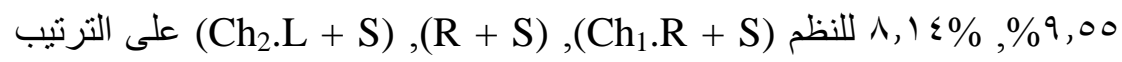

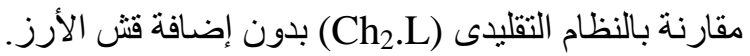

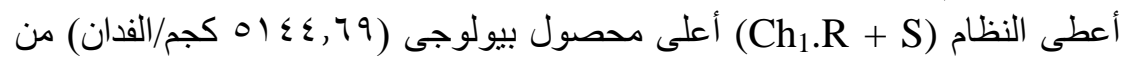

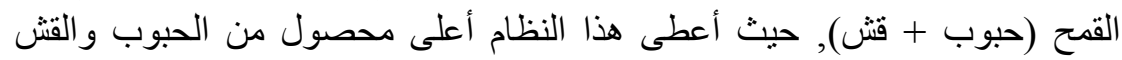

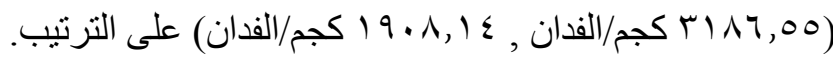

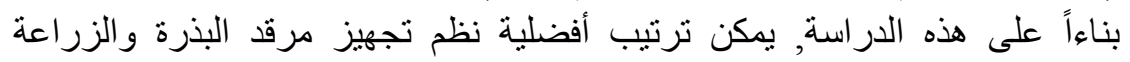

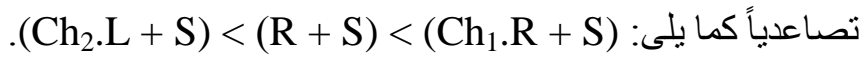

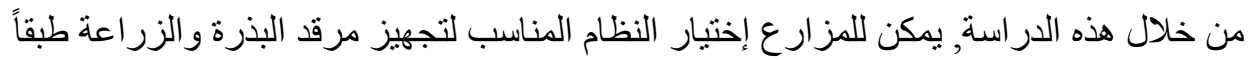

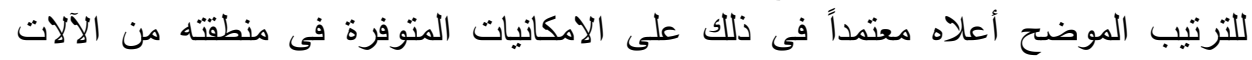

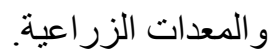

